\title{
POST-TRADUCCIÓN Y BODY ART: LAS REESCRITURAS DE ORLAN Y ANA MENDIETA
}

Irene Rodríguez Arcos $^{1}$ é doutoranda em Tradução e Mediação Intercultural pela Universidade de Salamanca (Espanha). Leciona atualmente no Departamento de Tradução. E-mail: ireneroa@usal.es

\begin{abstract}
Resumen
Partiendo del concepto de post-traducción de Genztler y entendiendo la traducción en sentido amplio, concebimos el cuerpo femenino como un espacio de reescritura ideológica, un elemento semiótico con significado al igual que para las artistas Orlan y Ana Mendieta, que lo utilizan como instrumento de trabajo para inscribir discursos en él. Analizarlo desde la Traductología puede ser de gran interés para abrir nuevas vías investigadoras.
\end{abstract}

Palabras clave

Post-traducción. Body Art. Orlan. Ana Mendieta. Reescrituras.

\section{1) Introducción}

Muy recientemente hemos sido testigos de hasta qué punto los Estudios de Traducción, en el intento de establecerse como una disciplina, han quedado restringidos a una lista canónica de autores y metodologías y se han acomodado en una "autocomplacencia" que impide hacer frente a fenómenos transculturales más amplios que vienen de la mano de un proceso globalizador sin precedentes en la Historia (BASSNETT, 2014; 2011). En este sentido, teóricos reconocidos de la Traductología, desde Maria Tymoczko (2007) que ya venía anunciándolo desde hace más de una década en su obra Enlarging Translation, se han embarcado en la aventura de expandir los límites de la definición tradicional de la disciplina. Entre ellos podemos contar a Bassnett, con su concepción de la traducción en dirección Outwards el prólogo a la obra de Genztler (2017) o a Johnston (2017; 2013), pero sobre todo a Genztler (2017), con su trabajo Translation and Rewriting in the Age of Post-Translation Studies. Hemos

\footnotetext{
${ }^{1}$ El presente artículo se inscribe en el proyecto de investigación "Violencia simbólica y traducción: retos en la representación de identidades fragmentadas en la sociedad global" (FFI2015-66516-P; MINECO/FEDER, UE), financiado por el Ministerio de Economía y Competitividad del Gobierno de España y el Fondo Europeo de Desarrollo Regional. Asimismo, la autora recibe subvención de la Junta de Castilla y León para la contratación predoctoral de personal investigador, cofinanciada por el Fondo Social Europeo (ORDEN EDU/1006/2015).
} 
llegado a la era de la "post-traducción", en la que esta, muy influida por las reescrituras, transvasa géneros y fronteras, como nos permite observar en su definición:

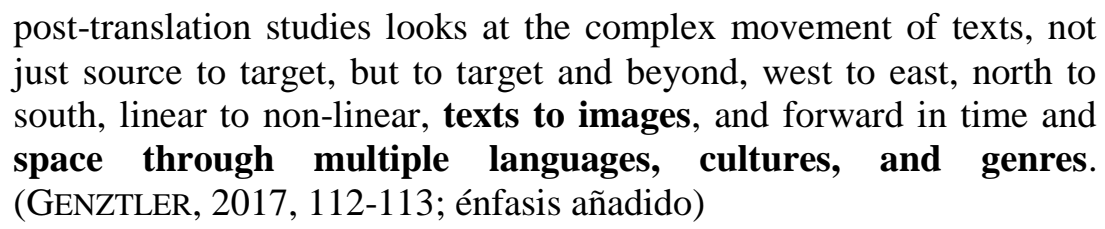

En este sentido, consideramos que una aproximación traductológica a la obra de las dos artistas que presentamos a continuación, Orlan y Ana Mendieta, puede resultar altamente reveladora en la medida en la que utilizan su cuerpo como un espacio de representación y de inscripción ideológica (HOLLIDAY y HASSARD, 2001, 2), es decir, de "post-traducción” según la definición de Genztler (2017) y de reescritura. De esta manera, el cuerpo femenino pasa a ser un sistema semiótico en el que se reflejan luchas y voluntades de poder (VIDAL, 2018, en prensa). Sin embargo, como observaremos a continuación, ellas no se conforman con pasar inadvertidas como una modelo más, pintada y observada por el hombre para el goce y disfrute de este, esa "male gaze" cómoda y privilegiada de la que nos alerta Mulvey (1975/1999). Nos referimos a aquellas modelos renacentistas perfectas como esculturas inertes sin vello, inmutables, siempre jóvenes, "closed and sealed" (HOLliday y HASSARD, 2001, 5). Por el contrario, ellas se atreven a mostrar el lado grotesco, lo abyecto en el sentido de Kristeva (1980/2004), pero, también lo natural del cuerpo cambiante con el paso del tiempo, lactante, en menstruación. Una representación que la sociedad ha excluido y considerado fuera de lugar, y que, aunque nos ha enseñado a no mirar (SHILDRICK y PRICE 1999, 7; $c f$. BORDO, 1993/2003), ellas nos muestran para desafiarnos y reinscribir en su cuerpo la negación a mostrarse como un "cuerpo dócil” más, en el sentido foucaultiano del término (1975/2002), moldeado por la ideología masiva del consumismo y las modas.

\section{2) Orlan: reescrituras y "post-traducción" carnal inacabada}

El cuerpo de Orlan constituye, sin lugar a dudas, una superficie de inscripción de discursos e ideologías, de lucha, de presiones. En el sentido foucaultiano del término, se encuentra moldeado por los discursos (FOUCAULT, 1975/2002) de la tecnología y de la medicina, pero también del arte, los cánones de belleza o la moda (INCE, 2000, 112). Se trata, pues, de narrativas (BAKER, 2006) que la artista va "post-traduciendo" (GENZTLER, 2017) en su cuerpo, y más concretamente en su carne, pues ella insiste en 
que se desenvuelve en los parámetros del "Carnal art", más que del "Body art", y especifica una serie de diferencias que detallaremos a más adelante, que van desde los objetivos del arte hasta la concepción de aspectos como el dolor, el proceso de la cirugía estética o la mirada misma.

Como precisa Ince en su introducción $(2000$, 1), si algo hace Orlan es llevar a la literalidad la expresión inglesa "operating theatre": fotografía, graba y emite las operaciones quirúrgicas que remodelan su rostro y su cuerpo, mientras permanece consciente leyendo fragmentos de literatura o psicoanálisis en el transcurso del proceso, lo que nos muestra que permanece en todo momento en control del proyecto. Así, esta artista vuelve a cuestionar las relaciones entre sujeto y objeto (JONES, 1998, 10), como hacía Cindy Sherman, al convertirse en lo uno y lo otro al tiempo, siendo dueña de sus representaciones y desafiando la posición cómoda de ciertos espectadores masculinos.

Según Ince (2000, 3), Orlan pretende responder mediante su obra a la pregunta de qué es lo que ven las mujeres, pues ya se ha contestado sobradamente a qué ven los hombres tras siglos de arte en los que la mujer ha posado como un objeto erótico para el goce contemplativo de ellos (BERGER, 1972; $c f$. MulveY, 1975/1999). Y desestabiliza el "pleasure and privilege of the "invisible guest"” (MULVEY, 1975/1999, 844), ese espectador privilegiado renacentista, a varios niveles: por el público en general, mediante las emisiones en directo de la cirugía, que recuerdan a la dialéctica de Kosut (2010, 190), entre un "body interiorised" (reducido a una serie de tejidos y órganos) y el "body spectacularised" (aquellos que esperan sufrir transformaciones y cambios radicales). En este caso, ambas tendencias se interrelacionan: la audiencia recibe imágenes desagradables del ámbito privado (fluidos, tejidos, huesos, etc.), porque Orlan revela las fases de la cirugía estética que todo el mundo esconde con absoluto recelo: los procedimientos y la recuperación. De hecho, se fotografía días después de las intervenciones con el rostro abultado y con los hematomas fruto de ellas (HIRSCHHORN, 1996, 118), como puede observarse en "Women look like the moon and my eyes like flowers" (1993), tomada seis días después de "Omnipresence", la séptima operación (INCE, 2000, 122). En ella, sobre un fondo urbano, y sosteniendo un ramo de narcisos, vemos a la artista con fuertes hematomas en ambos ojos, así como con la nariz y labios tremendamente hinchados.

A otro nivel también desafía la tradicional “male gaze” (MulveY, 1975/1999, 837) al incorporar de forma, al menos semipermanente, los cambios en su cuerpo de su concepto de lo abyecto, lo grotesco y lo monstruoso: "images of monstruos femininity 
are inadmisible to the male imaginary as they are unviewable by the male gaze" (INCE, 2000, 71). Como nos decía Berger (1972), lo que podemos mirar depende de nuestra situación y de nuestra experiencia, aparte de lo que establezcamos como monstruoso y abyecto depende de nuestros sistemas de inclusión, de lo aceptado:

En lugar de interrogarse sobre su "ser", se interroga sobre su lugar: “¿Dónde estoy?, más bien que ¿Quién soy?”. Ya que el espacio que preocupa al arrojado, al excluido, jamás es uno, ni homogéneo, ni totalizable, sino esencialmente divisible, plegable, catastrófico. Constructor de territorios, de lenguas, de obras, el arrojado no cesa de delimitar su universo, cuyos confines fluidos - estando constituidos por un no-objeto, lo abyecto - cuestionan constantemente su solidez y lo inducen a empezar de nuevo. Constructo infatigable, el arrojado es un extraviado. (KRISTEVA, 1980/2004, 16)

Y no solo es que Orlan nos obligue a mirar lo excluido, porque se viste con ello, sino que utiliza uno de los sistemas ideológicos patriarcales más fuertes para subvertirlo desde dentro, el de la cirugía estética: en lugar de crear otro "cuerpo dócil", para decirlo con Foucault (1975/2002), se vale del sistema para "post-traducir" (GENZTLER, 2017) lo abyecto en su propia carne y transgredir la narrativa de lo homogéneo (HIRSCHORN, 1996, 118).

My work is not intended to be against plastic surgery, but rather against the norms of beauty and the dictates of the dominant ideology which is becoming more and more deeply embedded in female... as well as masculine... flesh. Plastic surgery is one of the areas in which man's power can be most powerfully asserted on women's bodies. I was not able to obtain from male surgeons what I was able to achieve with a female surgeon, for I believe they wanted to keep me "cute". (ORLAN, 1995/2007, 314)

De esta manera, igual que lo han hecho otras artistas de la talla de Cindy Sherman, Orlan se niega a mostrar representaciones de sí misma tradicionales y canónicas, que hagan de la belleza un estándar fijo e inmutable, sino que apuesta más bien por el cuerpo cambiante y grotesco, por el que pasa el tiempo (HIRSCHORN, 1996, 118), la cirugía y la tecnología, algo que va de la mano con su concepción de la identidad, cambiante y fluida, y que exploran en el campo de la sociología autores como Hall (1996/1997) y Balibar (1988/1991), que nos demuestran que entenderla como un constructo que se va reconfigurando y reconstruyendo de forma constante, en oposición a una estructura monolítica y acabada, ayuda al ser humano a madurar y a aprender de la diferencia de otras comunidades.

A comienzos de los años setenta, Orlan adoptó el personaje de "Santa Orlan" (INCE, 2000, 13), y trabajó en representaciones de la figura femenina criticando la forma 
que había tenido la historia y la religión de separar y etiquetar tradicionalmente el papel de la mujer bien como santa, bien como prostituta. De esta manera, la encontramos en una serie de fotografías en las que inicialmente aparece vestida como una virgen y gradualmente se va desnudando hasta quedar totalmente desprovista de su ropa, con la mano derecha en el pubis y la izquierda en el pecho, emulando la Venus de Botticelli: nos referimos a One-off strip-tease with trousseau sheets, Espace Lyonnais d'Art Contemporain, 1976 (INCE, 2000).

En 1984, como hiciera Cindy Sherman más tarde en sus History Portraits, también se viste de virgen en White Madonna in Assumption y nos saca un pecho fuera, pudiéndose entender como una crítica a esa dualidad mencionada en el párrafo anterior, o como un elemento cómico y rebelde, pues Orlan también tiene esa actitud en algunas de sus obras. Lo mismo sucede en Black Virgin and Video, del mismo año, con telas de cuero negro y un espíritu en una línea más atrevida. Sigue moviéndose dentro de los parámetros religiosos, pero la dualidad se inclina más claramente hacia la narrativa de la modernidad, lo prohibido y la artificialidad al ir vestida de oscuro. En estos trabajos se fotografía a sí misma e introduce elementos de vestuario, maquillaje y atrezo en su propio cuerpo para "post-traducir" (GENZTLER, 2017) las narrativas (BAKER, 2006), discursos (FouCAULT, 1975/2002) e ideologías que acabamos de mencionar. Antes de pasar a las intervenciones quirúrgicas que, consideramos, se revelan como un paso más agresivo a la hora de inscribir discursos en el cuerpo femenino, nos detendremos analizar una obra más que nos interesa como etapa intermedia en este proceso, si bien es anterior cronológicamente.

Estamos hablando en este caso de Le baiser de l'artiste (1976), una foto escultura del torso desnudo de Orlan en la que se podía leer "Introduire 5 F" (cinco francos), acompañada de una ranura para la inserción de monedas. Los participantes en la performance veían caer su dinero por un tubo transparente hasta un contenedor situado en la entrepierna de la artista. Cuando la moneda descendía del todo, ella se inclinaba y le daba a la persona en cuestión un beso. A la altura del ombligo, se observaba el texto "Merci". Como advierte Ince:

the commodity in Orlan's performance was her own body, a woman's body, and by deploying it in this way Orlan pointed up how this exchange of commodities in the art market functions in exactly the same way as the economics of prostitution, in which the woman's body is most often the commodity being paid for. (INCE, 2000, 138) 
Una vez más, Orlan utiliza su propio cuerpo (o una representación de él en combinación con el objeto real) para "post-traducir" (GENZTLER, 2017) y criticar el capitalismo y los tintes patriarcales que le acompañan, que explotan los cuerpos de las mujeres, especialmente vulnerables en casos como los de la trata, y comercian con ellos como si su valor no fuera más allá que el de meros objetos (INCE, 2000, 140-141).

Sin embargo, al adoptar el rol de la "prostituta", salvando las distancias, pues ofrecía solo besos y no relaciones sexuales a sus potenciales "clientes", hay quien cree que asumió el riesgo de parecer cómplice con el sistema de economía patriarcal (ibid., 141). El problema de emplear la figura femenina para fines feministas, según Wolff (1990, 121), tiene que ver con los "pre-existing meanings, as sex object, as object of the male gaze, [which] always prevail and reappropriate the body, despite the intentions of the woman herself". No obstante, mediante esta obra, según Ince, lo que Orlan pretendía era:

miming patriarchal economic exchange precisely in order to expose and criticise it - a perfect example of the strategy of critical mimesis Irigaray suggests women avail themselves of in order to undermine and transform the functioning of patriarchal society. (INCE, 2000, 141)

A continuación, veremos esta forma de denuncia mediante "post-traducciones" (GENZTLER, 2017) más permanentes en su cuerpo, moldeado por las narrativas (BAKER, 2006) del "Carnal Art”, la medicina, la tecnología y la cirugía estética. Discursos, en el sentido foucaultiano (1975/2002) del término, que para Orlan no son autoritarios y reguladores, sino herramientas que le permiten conseguir vivir en una continua identidad fluida (INCE, 2000) y hacer de su cuerpo un autorretrato y un lienzo, una superficie de inscripción, como explica en su Manifiesto del Arte Carnal.

Nos referimos a un texto publicado por la propia artista, disponible en su página web en inglés y francés, en el que declara una serie de principios que nos permiten diferenciarlo del "Body Art" y del trabajo de otras feministas. En primer lugar, lo define:

Carnal Art is self-portraiture in the classical sense, but realised through the possibility of technology. It swings between defiguration and refiguration. Its inscription in the flesh is a function of our age. The body has become a "modified ready-made", no longer seen as the ideal it once represented; the body is not anymore this ideal readymade it was satisfying to sign. (ORLAN, 2018) 
Así recupera la importancia y la función de la carne ${ }^{2}$. De hecho, a diferencia de los procedimientos generales de la cirugía estética, los tejidos extraídos de Orlan se miden y pesan cuidadosamente y se guardan en relicarios que luego se exponen en galerías o se venden (INCE, 2000, 47-48). Para Orlan, "her body is a factory, her flesh its product" (Ibid., 48):

The object-based work of Orlan's which best illustrates this process is the sequence of large reliquary tablets "my flesh, the text and the language", each of which has at its centre resin-preserved flesh mounted amidst large-printed text of the same passage from Michel Serres' Le Tiers-Instruit which Orlan reads during operations, translated into many and little-known languages. Orlan's stated aim for this work is that the translation should continue until all known and dying languages have been exhausted, suggesting that the productivity of her body is being measured against the capacity of language(s) to describe and represent it. (Ibid., 48)

Estas palabras de Ince nos llevan a otro de los principios de Orlan, el del ateísmo, en el que Orlan especifica claramente que rechaza la idea bíblica que el verbo se haga carne, sino todo lo contrario: que la carne se haga palabra. Y esta idea cobra especial importancia, porque apoya nuestra hipótesis de hacer del cuerpo un texto en el sentido más literal posible: "Carnal Art transforms the body into language, reversing the biblical idea of the word made flesh; the flesh is made word. Only the voice of Orlan remains unchanged. The artist works on representation" (ORLAN, 2018).

Ahora nos detendremos en el tema del dolor, que para Orlan es fundamental de cara a distinguirlo del "Body Art": "As distinct from 'Body Art', Carnal Art does not conceive of pain as redemptive or as a source of purification" (ORLAN, 2018). De hecho, la artista afirma que se toma analgésicos después de las intervenciones, como todo el mundo, y compara la anestesia (epidural, en su caso), con la que nos han puesto alguna vez al ir al dentista (INCE, 2000, 63-64). Para ella, además, es el precio que hay que pagar por el arte, que está relacionado directamente con cuestiones de la mirada, en la que hay que superar el rechazo por lo abyecto: "I can observe my own body cut open without suffering!.... I can see myself all the way down to my viscera, a new stage of gaze" (ORLAN, 2018). En este sentido, en ocasiones se disculpa con su público por hacerle sufrir viendo determinadas imágenes: "When presenting her surgical work at conferences, in galleries, and in interviews to newspapers and journals, Orlan has more than once insisted that it is 'harder' on the viewer that it is on her. She does not suffer

\footnotetext{
${ }^{2}$ Otra de las características de este "Carnal Art" es el uso de la sangre (INCE, 2000), tal y como hacen Gina Pane o Ana Mendieta. En este sentido, destacamos una obra de Orlan de 1993: Finger drawing in blood.
} 
on the operating table: 'I am not a masochist"' (INCE, 2000, 56). Una afirmación también explícita en su Manifiesto, en relación con el ateísmo y su rechazo al martirio y al sufrimiento gratuito: "Carnal Art is not self-mutilation" (ORLAN, 2018).

Sin embargo, puede que esto no esté del todo claro. En relación con Reincarnation, la primera serie de operaciones de Orlan, advierte Ince:

a view which meets with broad agreement among the many intrigued by 'Reincarnation' is that a barely concealed aggression is implied in the act of having herself operated upon precisely in order to display her cut and bruised body to others. (Ince, 2000, 56)

Y, en ese sentido, Ince (2000, 49 y siguientes) percibe que debe de haber algo de narcisismo y erotismo en esa forma de identificación y mirada, en la línea de Mulvey, cuando afirma, aplicado al cine (y que perfectamente podría aplicarse en este sentido, pues Orlan filma y emite sus performances), que "the cinema offers a number of possible pleasures. One is scopophilia. There are circumstances in which looking itself is a source of pleasure, just as, in the reverse formation, there is pleasure in being looked at" (Mulvey, 1975/1999, 835). De hecho, en el Manifiesto, Orlan se expresa en los siguientes términos: "I can see to the heart of my lover and it's splendid design has nothing to do with symbolics mannered usually drawn. Darling, I love your spleen, I love your liver, I adore your pancreas and the line of your femur excites me" (ORLAN, 2018).

Con el principio de "clarificación", Orlan especifica que no está en contra de la cirugía estética, sino de los estándares que hacen de los cuerpos femeninos (y también de los masculinos) figuras homogéneas y dóciles. Defiende que el arte carnal debe ser feminista y comprometerse con los avances en medicina y biología, cuestionando el estado del cuerpo y las cuestiones éticas derivadas de ello. Para Orlan, como hemos podido comprobar, la identidad y el cuerpo son siempre productos inacabados: en términos de Shilling (1993/1997), es el "cuerpo como proyecto", un constructo siempre moldeable a placer. Por último, en la línea de la estética y del estilo, aclara que el arte carnal "loves parody and the baroque, the grotesque and the extreme. Carnal Art opposes the conventions that exercise constraint on the human body and the work of art. Carnal Art is anti-formalist and anti-conformist." (ORLAN, 2018) La "parodia" y lo "grotesco" nos traen sin duda a Bakhtin; mientras que lo "extremo" nos hace pensar en Kosut y su concepto de "extreme bodies":

Broadly conceived, an extreme body is characterized as a distinctively malleable, flexible and fluid entity. As such, extreme bodies engage in practices and regimes that push beyond the mundane or acceptable. 
Extreme bodies are the product of excessive physical modification, transformation, or activity, and also are aware of, and accept, the physical risks that come with radical carnal engagement. (KosuT, 2000, 186)

Una definición que encaja de lleno con las transformaciones a las que se somete Orlan, junto con ese "radical carnal engagement". El 30 de mayo de 1990 empezó con Reincarnation of Saint Orlan, una secuencia planeada de operaciones quirúrgicas en las que se centraría en cambiar un rasgo específico de su rostro:

\begin{abstract}
there was no one model for Orlan's self-remodelling; each feature is surgically resculpted to match a specific feature of a different great icon in the history of Western art: the nose of a famous unattributed School of Fontainebleau sculpture of Diana, the mouth of Boucher's Europa, the forehead of Leonardo's Mona Lisa, the chin of Botticelli's Venus and the eyes of Gérard's Psyche. (INCE, 2000, 6)
\end{abstract}

De esta forma no solo parodia la fragmentación fetichista del cuerpo femenino que hace la mirada masculina, sino que además cuestiona "notions of aesthetic unity and identical resemblance" (INCE, 2000, 46). Por supuesto, hubo otras lecturas de la performance (INCE, 2000, 44-45) en las que se entendía que la artista empleaba la cirugía estética para parecerse a estas musas de la belleza. Además, también estaban las críticas que hablaban del coste de los tratamientos: aunque ella es responsable de financiarlos, sabe que se encuentra en una posición privilegiada y que puede asumir costes que otro público no se puede plantear (HIRSCHORN, 1996, 120). Orlan negó rotundamente hacerlo por meras cuestiones estéticas y, en ese momento, adoptó una política de exposiciones en museos en la que siempre se acompañarían sus obras de una explicación o seminario de la propia artista para situarlas en contexto. De hecho, la elección de Orlan de esos rasgos no fue fortuita en absoluto:

Although her status as an artist of representation required the choice of visual images for her digital self-redesign, she selected the features of Mona Lisa, Venus, Diana, Europa and Psyche not for their appearance, but because of the mythical qualities and attributes these women possessed - the Mona Lisa for the androgyny resulting from the palimpsest of Leonardo da Vinci's self-portrait beneath her image, Venus because of her connection to fertility and creativity, Diana for her insubordination to men and aggressivity as the goddess of hunting, Europa because Gustave Moureau's painting of her is unfinished, and because her look to another continent showed her interest in an unknown future, and Psyche because of her need for love and spiritual beauty. (INCE, 2000, 46)

En 1993 tuvo lugar Omnipresence, la séptima operación, en la que se hizo los implantes sobre las cejas. En esta ocasión, la performance se retransmitió en directo por satélite a algunas galerías de arte y diversos centros en todo el mundo. No había más 
público en la sala que el equipo médico, pero toda una audiencia estaba virtualmente presente ya que se instaló un fax que permitía a la artista responder a las preguntas que el público le iba enviando. Este trabajo, especialmente relevante en una era en la que es protagonista la globalización y la movilidad virtual, así como el viaje incesante e instantáneo de discursos e ideologías, nos interesa especialmente en la medida en la que:

[t]he body had become digitally saturated, thoroughly and completely mediatized by the images and electronic signals transmitting the surgery to the world beyond the operating theatre. Orlan's 'omnipresence' was achieved via media technology, and was as such a prime example of postmodern media culture, in which physical reality has given way entirely to mediatized reality, and referents are subsumed in the continuous circulation of signs. (INCE, 2000, 104)

Todo lo que llegó a la audiencia, de este modo, fue a través de signos, traducciones pictóricas y lingüísticas en papel, de lo que estaba pasando en otra parte del mundo. Un cuerpo que al tiempo estaba, y no estaba, del que podía intuirse solamente su presencia mediante señales, huellas. Y, en esta línea totalmente diferente, vamos a situar a nuestra segunda artista: Ana Mendieta. En algunos trabajos va a aparecer de cuerpo presente $y$, en otros, nos va a dejar solo con su sangre, con sus huellas. Si Orlan era, en el título de la obra de Ince, la Millennial Female, Mendieta es el primitivismo, el "Land Art", la santería, la desnudez, la fertilidad y la sangre. El devenir ambiente, para decirlo con Braidotti (2006/2009): el cuerpo ausente.

\section{3) Ana Mendieta: el devenir ambiente}

Ana Mendieta, de origen cubano, llegó a Estados Unidos cuando tenía doce años auspiciada por la operación Peter Pan. Fuera de lugar, el sentimiento de exilio la acompañó toda su vida y marcaría posteriormente su identidad y su carrera artística, como comprobaremos más adelante cuando veamos las influencias de la santería o de la concepción de la naturaleza como un reencuentro maternal (CABAÑAS, 1999, 12; RAINE, 1996; BEST, 2007). Entre los límites del "Body Art" y del "Land Art", analizaremos varios trabajos en los que utiliza su cuerpo para "post-traducir" ideologías que denuncian violencia contra la mujer mediante elementos como la sangre, que para nuestra artista no solo indica violencia, sino también fertilidad y vida, siguiendo los rituales de la santería. Posteriormente veremos otras obras y performances en las que se fusiona con la naturaleza y observaremos primero su cuerpo y luego sus huellas, como en la serie Siluetas. 
Según Cabañas $(1999,12)$, el siguiente poema puede ayudarnos a comprender la obra de Ana Mendieta. Coincidimos con ella, y lo tendremos de cabecera para configurar este tercer epígrafe, porque consideramos que apoya nuestra hipótesis de "post-traducción" y de inscripciones en el cuerpo femenino:

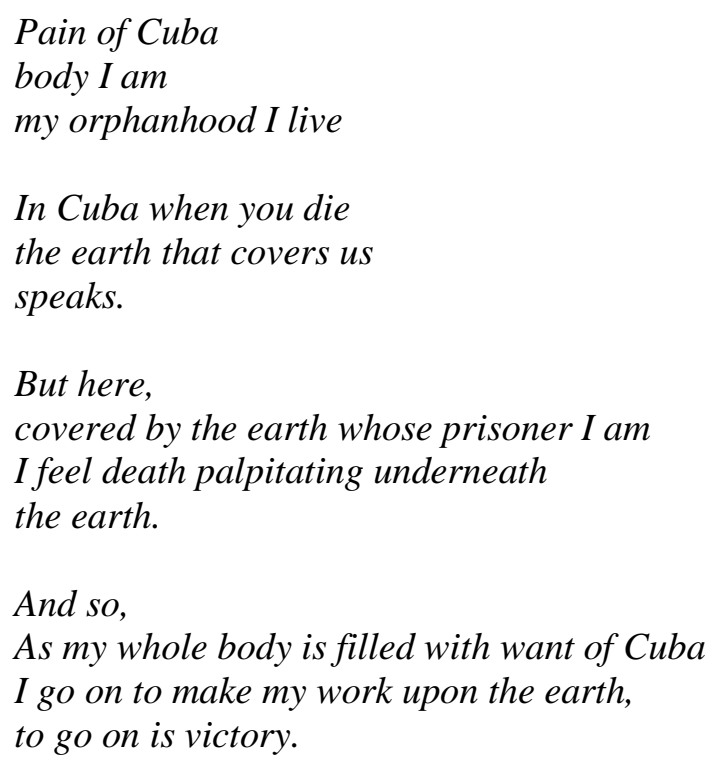

En primer lugar, con "pain", volvemos al sentimiento de exilio y nostalgia hacia la tierra de nacimiento, que se somatiza y se mezcla con el "cuerpo" en un dolor físico. La persona se siente "huérfana", lo que tiene mucho que ver, ya lo comprobaremos, con la serie Siluetas, en las que ella se representa aislada y en soledad, y se reencuentra de una forma maternal con la naturaleza (RAINE, 1996). El resto lo dejamos para más adelante, cuando sigamos con otros trabajos. Para Cabañas, los dos primeros versos del poema son "the individual collective body of Ana Mendieta as she communicates her personal experience and critiques the inherited social relations where women and ethnic Others are viewed as objects" (CABAÑAS, 1999, 12).

De esta manera llegamos a Rape Scene (1973): una obra de una tremenda dureza visual en la que Mendieta critica una serie de violaciones producidas en el campus de Iowa (CABAÑAS, 1999). En ella, se ve a la artista de espaldas, doblada sobre una mesa, con una camiseta y desnuda de piernas para abajo con las nalgas y piernas salpicadas en sangre atada a la pata de una mesa. Asimismo, se preocupó de desordenar su apartamento. Como sucede con Orlan, utiliza su propio cuerpo para "post-traducir" (GENZTLER, 2017) una narrativa (BAKER, 2006): la de denunciar la violencia sexual contra la mujer, volviendo de nuevo a incomodar a ese "invisible guest" de Mulvey (1975/1999), pero también a cualquier otro espectador con sensibilidad hacia la violencia de género. 
En esta ocasión, la relación entre sujeto y objeto (JONES, 1998) se revela de muy difícil descripción, si bien es cierto que la artista en teoría solo está recreando la escena, en línea con las palabras que citábamos de Wolff (1990) acerca de que tenemos que enfrentarnos a los problemas que existen para no prejuzgar el cuerpo de la mujer con significados anteriores cuando este se usa para fines feministas. Puede que el obstáculo resida en la dureza de la lectura de la imagen, ya que, aunque la intención de la artista sea la de la denuncia, esta nos impida mirarla como sujeto y la intersubjetividad se incline más hacia el lado de la pasividad que el de la actividad.

En la misma línea, en 1974, con la performance en vídeo Blood Writing ${ }^{3}$, denuncia la violencia de género escribiendo en pintura roja con sus propias manos "SHE GOT LOVE" en una pared blanca con sangre. Ese "she" somos todas nosotras, todas las mujeres; mientras que "love" es una burla, una antítesis: "marriage, conceived as a bond of mutual and reciprocal love, becomes bondage when female subjectivity is denied and 'she' becomes the object of masculine aggression" (CABAÑAS, 1999, 13). Según Cabañas (Ibid.), también pudo tener que ver la circunstancia familiar de su hermana, que había sufrido violencia de género meses antes, lo que terminó en divorcio.

En estos trabajos, la artista utiliza la sangre y el color rojo como una muestra de dolor. En los siguientes, notaremos la influencia de la santería y se convertirá en un elemento religioso, de fertilidad, de vida y de poder. Como afirma Cabañas (Ibid., 13), "ritual also expresses how culture is written on the body. Mendieta draws attention to her own body as a locus for cultural experience" (énfasis añadido), y así también lo demuestra Mendieta en su obra. En Sweating Blood (1973), una performance grabada en vídeo, se observa cómo la sangre va cayendo con por su rostro mientras ella está en un estado de posesión común en las prácticas de la Santería, quizá por la diosa Ochun (Ibid.). Otra obra relacionada es Body Tracks, grabada por primera vez en 1974: unta sus brazos en sangre, no sabemos si suya o tomada de alguna otra fuente y, de rodillas, dibuja una suerte de semicírculos, convirtiéndose, para decirlo con Cabañas, en un "living brush" (Ibid., 13). También nos recuerda Cabañas que se pueden oír tambores afrocubanos en el vídeo de la performance, lo que nos trae ecos de la Santería nuevamente y del primitivismo. La silueta dibujada recuerda ligeramente a un triángulo invertido, para algunos símbolo de la fertilidad y de lo femenino, una lectura dentro de lo lógico si tenemos en cuenta el resto de la obra de Ana Mendieta.

\footnotetext{
${ }^{3}$ Puede consultarse en el siguiente enlace: https://vimeopro.com/user10398349/she-got-love-bloodwriting-1/video/69377546. Último acceso el 18 de marzo de 2018.
} 
En 1972 realiza Death of a Chicken, en el que la artista, completamente desnuda, decapita un pollo a la altura del pubis y deja que la sangre del animal salpique su cuerpo. En Bird Transformation, del mismo año, se unta de sangre y se cubre de plumas blancas, para transformarse en el gallo que se sacrifica en los rituales de la Santería, y deja el sexo al descubierto. De nuevo, utiliza su propio cuerpo para "post-traducir" (GENZTLER, 2017) una ideología en la que ella vuelve a ser víctima, como minoría:

\begin{abstract}
the act of sacrifice is integral to Santeria initiation rites, and Mendieta communicates the pain of exile and displacement in these ritual perfomances. Like the uprooted Santeros whose rituals reconstitute ties to the community, Mendieta, in a shared bodily experience of ritual, places herself in a community that helps her feel whole. (Cabañas, 1999, 13)
\end{abstract}

Los siguientes trabajos de Mendieta se sitúan en una línea completamente diferente. Ahora pasaremos al territorio del "Land Art", aunque es cierto que no abandona del todo el "Body Art", sobre todo al principio, en la serie del Árbol de la vida y en algunas de las fotografías de Siluetas. Luego sí veremos cómo, gradualmente, el cuerpo va desapareciendo, y solo quedan huellas del él, aunque para crear sus obras lo haya utilizado al menos como molde. Afirma Raine $(1996,236)$ que, esta parte de la obra de la artista en concreto, ha sido en ocasiones descrita como "apolitic, ahistoric or primitive", dada la falta de especificidad de los entornos, pero la crítica artística deja claro que el mensaje de Mendieta es:

intervention into the interrelated social discourses of patriarchal, imperialist and ecological domination, a resistance to dominant narrative of western history and its universalized subject whose relation to its Others (woman, non-western cultures, landscape) is structured by the phallic either/or of assimilation or rejection. (RAINE, 1996, 247)

En términos de Ana Mendieta, supone un diálogo entre el entorno y el cuerpo femenino (citada en RAINE, 1996, 228), en el que utiliza materiales como tierra, arena, piedras, agua, pólvora, fuego, plantas, flores, árboles, sangre, cabello humano y su propio cuerpo para trazar su silueta en el ambiente (Ibid.). Así aparece en la serie Árbol de la vida, cubierta de lodo casi camuflada en el tronco de un árbol de pie, con los brazos abiertos en cruz y los codos hacia arriba, adoptando una postura de deidad. Si bien es cierto que su cuerpo ofrece una textura diferente, es prácticamente parte del entorno, está fusionada con él. Como afirma Raine, su intención es

both a desire to "become one" with a maternal earth, and "a personal will to continue being 'other" to dominant white society (including American feminism, which she denounced as "basically a white 
middle class movement"). That is, she used the meeting of female body and land as a deliberately oppositional position of identification with modern industrial America's excluded Others, invoking an animistic view of nature as "omnipresent female force" and drawing on concepts and motifs from ancient and non-western cultural traditions, particularly Santería, a Cuban syncretic religion based on African Yoruba and popular Catholic beliefs and practices. (RAINE, 1996, 235)

El cuerpo se convierte por lo tanto en una metáfora que media entre la sociedad y el entorno natural (Ibid.). Los entornos escogidos, si bien es cierto que se identifican con total exactitud en los títulos de las fotografías, no se encuentran con facilidad, ya que contienen pocas marcas distintivas y las imágenes se concentran en la forma humana. Por esa razón, Raine habla de una aparente "falta de localización" (Ibid., 236). En este sentido, "Mendieta's work too can be read as resisting hegemonic history through a strategic deployment of the geographic" (Ibid., 237), en el que los espacios representados constituyen una vuelta a lo primitivo y lo natural, sobre todo en las series Rupestres, donde no hay fronteras ni modernidad, ni colonizadores ni esclavos.

La serie Siluetas representa la idea de una tierra feminizada "by showing the female body incorporated into various natural environments; rivers, the air, the land and the liminal zones of seashore and riverbank" (BEST, 2007, 58) que, además, precisa Cabañas (1999), se trata de elementos de fusión y transformación para nuestra artista. Según Raine (1996, 238), la relación que ella establece con el paisaje se produce necesariamente a través del cuerpo, que se convierte en un

site of negotiation between materiality, psychic drives, and social and cultural inscriptions, and is therefore central to a practice in which the encounter with the non-human and the exploration of the human psychic and social existence can occupy the same space, and indeed are posited as inseparable. (Ídem; énfasis añadido)

En este sentido, no podemos olvidar la relación paralela que establecen Tymozcko y Genztler con la traducción, que también se convierte en un foco continuo de tensión y negociaciones: "as a result, translators must make choices, selecting aspects or parts of a text to transpose and emphasize. Such choices in turn serve to create representations of their source texts, representations that are also partial" (Tymozcko y Genztler, 2002, xviii). Mendieta utiliza su cuerpo como una suerte de molde en el que luego dejará su impronta en el paisaje. Sabemos que es una figura femenina porque la identificamos con la artista, pero podría tratarse de cualquier persona y, además, podría estar situada tanto boca arriba como boca abajo: 
These departicularized or generalized images nonetheless also represent Mendieta herself; it is her own body that provides the template for the silhouettes, in the minimal form of her height or the more exact form of an outline of her actual body. The muted form of this self-representation means that it is at once her in particular and potentially every person that is reconnected to the earth. (BEST, 2007, 72)

Como hemos adelantado, Mendieta siente Siluetas y la comunión con la naturaleza como un retorno a lo maternal:

union with the earth is equated with a "return to the maternal source": landscape, in the form of various chosen sites, serves as a trope or substitute not only for the homeland of Mendieta's particular exile, but also for the maternal body in its dual role as both "figure" and "ground" for the process of imaginary self-formation. (RAINE, 1996, 244)

Porque, recordemos, en el poema se hablaba de orfandad, lo que explica "the traces of the solitary figure in these images [which] evoke a strong sense of isolation, aloneness, even loneliness, alongside the assertion of a temporary place in nature" (BEST, 2007, 78). Y es que, tal y como afirma Raine (1996, 239), las imágenes no ofrecen territorio para la contemplación narcisista o la identificación sosegada. Advierte que las fotografías evocan un déjà $v u$ a dos niveles: en primer lugar, por lo cotidiano de las escenas y, en segundo, por la recurrencia de la silueta, cuya forma antropomórfica recuerda a algo tremendamente familiar que aun así se nos revela como extraño a través de su repetición mediante los diferentes enclaves y materiales empleados (Ibid.). Asimismo, la familiaridad se interrumpe constantemente cuando la obra se percibe como una serie: de ahí, que Best argumente que una de las posibles lecturas de Siluetas pueda hacerse en términos de la teoría de la performatividad de Butler (1993): "Mendieta's Silueta works are able to sustain this reading because they emphasize repeated actions, a key issue in Judith Butler's idea of gender as performance, and they repeat one of the abiding narratives which has determined an understanding of femininity: the link between the body of a woman and nature" (BEST, 2007, 64).

De esa manera, además defiende el trabajo de la artista de las críticas de recurrir a representaciones esencialistas de la figura femenina. De hecho, uno de los argumentos a favor de Siluetas es que se centra en la ausencia del cuerpo, especialmente en los últimos trabajos de la serie, en los que solo vemos huellas de él, más que una imagen del cuerpo en sí (Ibid., 57). Para decirlo con Best, hablamos de un "doubly displacement", ya que Mendieta primero utiliza su cuerpo como molde para crear una 
forma en el paisaje $\mathrm{y}$, posteriormente, a lo que accedemos es a una fotografía de esa impronta: "mostly, we see then, traces of traces of the body" (Ibid., 65).

No obstante, advierte Best $(2007,62)$ que también aparecen una serie de películas, que Mendieta denomina "acciones” y que se incluyen dentro de la serie Siluetas. Estas son Genesis in Mud, Flower Person, Corazón con roca de sangre, Silueta sangrienta y Alma Silueta en fuego. En la primera podemos ver a la artista respirando bajo una capa de lodo y, como se afirma en el artículo,

if these films are included in the Silueta series, then this constitutes the greatest disruption to established interpretations of the limits of the series and its meanings. The Silueta series is not just concerned with traces of the body or the absence of the body, an argument that applies well to most of the photographs, but it also includes the body itself". (Ibid., 62-63)

Y es que, también nos recuerda Best (Ibid., 73), la artista describió la serie en términos de "visualizing the body as an extension of nature and nature as an extension of the body". Ahora creemos conveniente volver al poema con el que abrimos el epígrafe, y entendemos cómo las palabras "the earth that covers us speaks" adquieren nuevos significados. Asimismo lo hacen los versos "covered by the earth whose prisoner I am" o "I feel death palpitating underneath the earth", porque, como decíamos, estas imágenes no relajan, no nos dejan en un lugar privilegiado como espectadores. Observamos con claridad cómo no todo es celebración de la naturaleza en la obra de la artista; también se perciben ciertos tonos ambivalentes en esa relación:

Mendieta's images combine, then, a kind of ritualized communion with nature - a celebration of its power and diversity in which the body participates and paradoxically, alongside the sense of transience, also a faint sense of immobility, and restriction. (BEST, 2007, 78)

Estas sensaciones se pueden percibir claramente en las películas o en algunas Siluetas o fotografías del Árbol de la vida, en las que parece estar presa y que Best $(2007,78)$ describe como "disorienting" o "claustrophobic". De alguna manera, parece que no deja estar presente la idea de que en la misma medida que la naturaleza puede dar vida, también puede quitárnosla (Ibid.) y, en ese sentido, parece que las Siluetas están "subject to immanent dissolution: at any moment, the flowers will scatter or decompose, the mud or sand will wash away, the flames will burn out, etc." (RAINE, 1996: 239). Como afirma Best $(2007,75)$, la tierra finalmente reclama lo suyo.

Las fotografías reflejan un instante preciso que permanece congelado para toda la eternidad: "the eternity of nature is evoked as well as the immediacy of experience" (MENDIETA, citada en BEST, 2007, 76). Es, a la vez, presencia y ausencia: 
both sensuous and schematic, the anthropomorphic outlines simultaneously insist on the presence of the body and mark its almost palpable absence, like the chalk drawings used by the police to mark the position of an absent corpse. (RAINE, 1996, 240)

Y no podemos evitar recordar a Barthes (1980/1992) y a su Cámara Lúcida, con la "momificación del referente" y de un "antes que ya no está aquí". No puede ser más cierto para Ana Mendieta, que sufrió un trágico destino al caer por la ventana de su apartamento: "the most powerful sense of animate nature belongs to the future of the image when the body is reclaimed" (BEST, 2007, 76). Para decirlo con Braidotti (2006/2009), el 8 de septiembre de 1985 Ana Mendieta devino finalmente ambiente, la más tenue de las minorías:

\begin{abstract}
Mendieta's oppositional practice is not only the private ritual of the artist's encounter with the earth, but also its documentation and exhibition in photographic form; and within the private and encounter, the real body and landscape are always already inscribed with personal, social and historical meanings, and experienced through imaginary and conceptual bodies and landscapes produced by various psychic events and social discourses. (RAINE 1996, 247; énfasis añadido)
\end{abstract}

\title{
4) Conclusiones
}

El trabajo de estas dos artistas enmarcadas en la corriente del "Body Art" nos ha permitido analizar y percibir el cuerpo como un sistema de representación (y de quién tiene autoridad para hacerlo) de luchas y poder, de inscripción de discursos e ideologías, en resumen, como un texto en sí mismo y una superficie de "post-traducción", para decirlo con Genztler (2017). Expandir los límites de la definición tradicional de traducción permite, como introdujimos al principio de este artículo, abarcar aspectos transculturales más amplios (BASSNETT, 2014) y abrir nuevas vías y perspectivas para la investigación en Traductología. Como acertadamente indica Bielsa (2016), mirar con ojos traductológicos la medida en la que se articulan los ejes global-local en este proceso globalizador puede ser de gran interés, y en este sentido, concebir el cuerpo como texto, nos permite trasladar la hipótesis aquí planteada a diversos espacios y territorios, como son el cine y la publicidad, este último de elevada pertinencia y relevancia dada su actualidad y la violencia simbólica (Bourdieu 1998/2000) que se ejerce contra la representación de la mujer en medios de comunicación. Si entendemos que los publicistas utilizan el cuerpo de las modelos en la misma medida que las artistas el suyo, para inscribir en ellos los cánones de belleza patriarcal que predominan en sociedades occidentales y hacer de ellos "cuerpos dóciles" en el sentido foucaultiano del término (1975/2002), analizar y observar las reescrituras femeninas a través de las 
culturas desde esta novedosa concepción de los Estudios de Traducción puede arrojar una valiosa luz a la dimensión ética de la disciplina que merece ser estudiada con rigor y urgencia.

\section{Referencias}

BAKER, Mona. Translation and Conflict: A Narrative Account. London/New York: Routledge, 2006.

Balibar, Étienne y Wallerstein, Immanuel. Race, Nation, Class. Ambiguous Identities. London/New York: Verso, 1988/1991.

BARTHES, Roland. La cámara lúcida. Nota sobre la fotografía. Trad: Joaquim SalaSanahuja. Barcelona: Paidós, 1980/1992.

BASSNETT, Susan. Foreword. In: GENTZLER, Edwin: Translation and Rewriting in the Age of Post-Translation Studies. New York/London: Routledge, 2017. p. ix-x.

BASSNETT, Susan. From Cultural Turn to Transnational Turn: A Transnational Journey. In: Alvstad, Cecilia, Helgesson Stefan y WATSON David (eds.). Literature, Geography, Translation. Studies in World Writing. Cambridge: Cambridge Scholars Publishing, 2011. p. 67-80.

BASSNETT, Susan. Translation studies at a cross-roads. In: BREMS, Elke, MEYLAERTS, Reyne y VAN DoOrSLAER, Luc (eds.). The Known Unknown of Translation Studies. Amsterdam/Philadelphia: John Benjamins, 2014. p. 17-27.

BERGER, John. Ways of Seeing. London/New York: Penguin Books, 1972/1977.

BESt, Susan. The Serial Spaces of Ana Mendieta. Art History, v. 30, nº 1, p. 57-82, 2007.

BIELSA, Esperança. Cosmopolitanism and Translation. Investigations into the experiences of the foreign. London/New York: Routledge, 2016.

BORDO, Susan. Unbearable Weight. Feminism, Western Culture and the Body. Berkeley: University of California Press, 1993/2003.

BOURDIEU, Pierre. La dominación masculina. Trad: Joaquín Jordà. Barcelona: Anagrama, 1998/2000.

BRAIDOTTI, Rosi. Transposiciones. Sobre la ética nómada. Trad: Alcira Bixio. Barcelona: Gedisa, 2006/2009.

BUTLER, Judith. Bodies that Matter. On the Discursive Limits of "Sex". London: Routledge, 1993.

CABAÑAS, Kaira M. Ana Mendieta: 'Pain of Cuba, Body I am'. Woman's Art Journal, v. $20, \mathrm{n}^{\circ} 1$, p. $12-17,1999$. 
FOUCAULT, Michel. Vigilar y castigar. El nacimiento de la prisión. Trad: Aurelio Garzón del Camino. Buenos Aires: Siglo veintiuno editores Argentina, 1975/2002.

Gentzler, Edwin. Translation and Rewriting in the Age of Post-Translation Studies. New York/London: Routledge, 2017.

HALl, Stuart. Who Needs 'Identity'? In: Hall, Stuart Y Du GAY, Paul (eds.): Questions of Cultural Identity. London: Sage Publications Ltd, 1996/1997. p. 1-17.

HIRSCHHORN, Michelle. Orlan Artist in the post-human age of mechanical reincarnation: body as ready (to be re-) made. In: PollocK, Griselda (ed.): Generations and Geographies in the Visual Arts. Feminist Readings. London/New York: Routledge, 1996. p. 110-134.

HollidAY, Ruth y HASSARD, John. Contested Bodies. An Introduction. In: HollidAY, Ruth y HASSARD, John (eds.): Contested Bodies. London/New York: Routledge, 2001. p. 1-17.

INCE, Kate. Orlan. Millennial Female. Oxford: Berg, 2000.

JoHnSTON, David. Professing translation: the acts-in-between. Target: International journal of translation studies, v. 25, $\mathrm{n}^{\circ} 3$, p. 365-384, 2013.

Johnston, David. Prólogo. In: Vidal Claramonte, $\mathrm{M}^{\mathrm{a}}$ del Carmen África. Dile que le he escrito un blues. Del texto como partitura a la partitura como traducción en la literatura latinoamericana. Madrid/Frankfurt: Vervuert Iberoamericana, 2017. p. 11-14.

JONES, Amelia. Body Art. Performing the Subject. Minneapolis: University of Minnesota Press, 1998.

Kosut, Mary. Extreme Bodies/Extreme Culture. In: Moore, Lisa y Kosut, Mary (eds.): The Body Reader. New York and London: New York University Press, 2010. p. 184-200.

Kristeva, Julia. Poderes de la perversión. Trad: Nicolás Rosa. México D.F.: Siglo XXI editores, 1980/2004.

MulveY, Laura. Visual Pleasure and Narrative Cinema. In: BRAUDY, Leo y COHEN, Marshall (eds.): Film Theory and Criticism: Introductory Readings. New York: Oxford UP, 1975/1999. p. 833-44.

ORLAN on becoming-Orlan. I do not want to look like... In: FRASER, Mariam y GRECO, Monica (eds.). The Body. A Reader. London/New York: Routledge Student Readers, 1995/2007. p. 312-315.

ORLAN. Manifiesto of Carnal Art. Disponible en: http://www.orlan.eu/texts/. Acceso el 19 de marzo de 2018. 
RAINE, Anne. Embodied geographies: subjectivity and materiality in the work of Ana Mendieta. In: Pollock, Griselda (ed.). Generations and Geographies in the Visual Arts. Feminist Readings. London/New York: Routledge, 1996. p. 228-249.

SHILDRICK, Margrit y PRICE, Janet. Openings on the Body: A Critical Introduction. In: PrICE, Janet y ShILDRICK, Margrit (eds.). Feminist Theory and the Body: A Reader. Edinburgh: Edinburgh University Press, 1999. p. 1-14.

SHILling, Chris. The Body and Social Theory. London: Sage Publications, 1993/1997.

Tymoczko, Maria y Gentzler, Edwin (eds.). Translation and Power.

Amherst/Boston: University of Massachusetts Press, 2002.

TYMOCZKO, Maria. Enlarging Translation, Empowering Translators. Manchester:

St. Jerome, 2007.

Vidal Claramonte, $M^{\mathrm{a}}$ del Carmen África. The body as a Semiotic System of Representation. In: Federici, Eleonora y Parlati, Marilena (eds.). The Body Metaphor: Cultural Images, Literary Perceptions, Linguistic Representations. Perugia: Morlacchi Editore, 2018 (en prensa), p. 17-26.

WolfF, Janet. Feminine Sentences. Essays on Women \& Culture. Cambridge: Polity Press, 1990.

\author{
PÓS-TRADUÇÃO E BODY ART: \\ AS REESCRITURAS DE ORLAN E ANA MENDIETA
}

\begin{abstract}
Resumo
Partindo do conceito de pós-tradução de Genztler e entendendo a tradução num sentido amplo, concebemos o corpo feminino como um espaço de reescritura ideológica; um elemento semiótico, do mesmo modo que o fazem as artistas Orlan e Ana Mendieta, que o utilizam como instrumento de trabalho escrevendo discursos sobre o mesmo. Analisálo do ponto de vista dos Estudos da Tradução pode ser de grande interesse para abrir novas linhas de investigação.
\end{abstract}

Palavras-chave

Pós-tradução. Body Art. Orlan. Ana Mendieta. Reescrituras. 